\title{
CLIMATE CHANGE IMPACT ON TOGO'S AGRICULTURE PERFORMANCE: A RICARDIAN ANALYSIS BASED ON TIME SERIES DATA MIKÉMINA, P. \\ http://dx.doi.org/10.4314/ejesm.v6i4.7
}

\begin{abstract}
Received 17th March 2013; accepted 19th June 2013

This paper applies Ricardian approach to measure the effect of climate change on agriculture performance in Togo using time series data from the period 1971-2004. The study examines the relationship between net farm revenue and climate variables. Net farm revenue is regressed on climate and other variables. The findings show that there exists a non linear relationship between agricultural added value and recorded precipitations during the cropping period. More specifically, relatively high precipitation seems to have positive impact on net farm income during the rainy seasons. Marginal impacts are mostly in line with the Ricardian model, showing marginally increasing precipitation during rainy season would increase net farm income, but reduce by the square terms of this season. Other variables such as ratio of irrigated farm land and farm labour are found to have positive impact on net farm value but not agricultural machinery. Climate change impact simulations reveal that changes in climate attributes will reduce agricultural added value per hectare by a value ranging from $7.11 \%$ in 2025 climate scenario to $15.24 \%$ in 2050 climate scenario. In terms of GDP, climate change will cost Togo a proportion between 2.84 and 6 percent. Conclusively, the impact of climate change on agriculture seems to be varied with the temperature and precipitation in different seasons. Climate change impacts are driven by decreases in precipitations implies that adaptation efforts should target more drought-resistant crop varieties and technologies.
\end{abstract}

Keywords: Climate change, Agricultural Added Value, Ricardian analysis, Togo

\section{Introduction}

The growing evidence from the Intergovernmental Panel on Climate Change (IPCC) that climate will change as greenhouse gases accumulate (IPCC, 2007) has added urgency to the need to understand the consequences of these changes. Higher temperature and declining rainfall patterns, as well as increasing frequency of extreme climate events (such as droughts and floods), are the expected future climate in tropics (IPCC, 2007).

In Togo, for example, annual rainfall is highly variable on inter-annual and inter-decadal timescales showing an overall decreasing trend in the period 1960 to 2006 and high frequency of droughts and floods predicted to intensify in $21^{\text {st }}$ century Predictions for 2025 by SCENGEN model show that declining trend in rainfall is set to continue and the country is expected to be 10$30 \%$ drier than the previous 50 years (CNI, 2001).

These predicted changes in climate are expected to have differential impacts on agricultural productivity, food security and other sectors across spatial and temporal scales. In tropics and Africa in particular, changes in climate are expected to be detrimental to agricultural livelihood (IPCC, 2007; IPCC, 2001). Recent studies suggest that agricultural crop productivity in Africa will be adversely affected by any warming above current levels (Kurukulasuriya et al., 2006; Kurukulasuriya and Mendelsohn, 2007; Seo and Mendelsohn, 2007).

Local ecosystems provide the main source of livelihood for many of the world's poor. Most of the rural poor in Togo rely for their livelihood and food security on highly climate sensitive rain-fed subsistence or small-scale farming, pastoral herding and direct harvesting of natural services of ecosystems such as forests and wetlands (CNI, 2001). The productivity of this livelihood base is highly vulnerable to climate related stresses, such as changes in temperature, precipitations (both amount and variability), and increase frequency of droughts and floods. The vulnerability of the majority of poor in Togo in climate related stresses is worsened by widespread poverty, HIV/AIDS, lack of access to resources (e.g. land, water, credit etc.) and management capabilities.

Agricultural production, indeed, remains the main source of livelihoods for most rural communities in developing countries and Togo in particular. Here, agriculture provides a source 
of employment for more than 70 percent of the population and contributes about 40 percent of Gross Domestic Product (GDP) (CNI, 2001). Given its climate relative sensitivity despite its major role, the estimates of climate change consequences on Agriculture is crucial. The objective of this study is therefore to estimate climate change impact on agriculture net revenue. To our knowledge, no study published to date investigated climate change impacts on agricultural performances in Togo. Estimating the impacts of climate changes can provide important entry points for potential adaptation policy insights in order to mitigate the adverse climate change impacts.

\section{Methodology \\ Study Area}

This research work was conducted in Togo State (Figure 2). Togo is a small West African nation. It borders the Bight of Benin in the south; Ghana lies to the west; Benin to the east; and to the north Togo is bound by Burkina Faso. Togo lies mostly between latitudes $6^{\circ}$ and $11^{\circ} \mathrm{N}$, and longitudes $0^{\circ}$ and $2^{\circ} \mathrm{E}$. In the north the land is characterized by a gently rolling savanna in contrast to the center of the country, which is characterized by hills. The south of Togo is characterized by a savanna and woodland plateau which reaches to a coastal plain with extensive lagoons and marshes. The land size is $56,785 \mathrm{~km}^{2}$, with an average population density of 253 people per square mile $\left(98 / \mathrm{km}^{2}\right)$. From 2010 census the country has a population of $6,191,155$.

The climate is generally tropical with average temperatures ranging from $27.5{ }^{\circ} \mathrm{C}$ $\left(81.5^{\circ} \mathrm{F}\right)$ on the coast to about $30^{\circ} \mathrm{C}\left(86^{\circ} \mathrm{F}\right)$ in the northernmost regions, with a dry climate and characteristics of a tropical savanna. To the south there are two seasons of rain (the first between April and July and the second between September and November), even though the average rainfall is not very high.

\section{Main Climatic Risks in Togo}

The two main climate risks facing Togo are flooding and drought. According to the country's NAPA (National Adaptation Program of Action of Togo), sectors that will be most affected by climate change are agriculture, health, fisheries, water, and coastal resources. Across the country, drought and floods pose the greatest threats from natural hazards:

Floods - Between 1925 and 1992, Togo endured 60 flood events that caused major damage to infrastructure, as well as significant loss of life. Over the past decade, six major floods have inflicted significant environmental, social, and economic damage. Governance deficiencies and a lack of appropriate disaster preparedness plans have severely hampered the country's ability to respond to these hazards. The successive flooding has leeched essential nutrients from top soils, accelerated erosion, and degraded the quality of the arable land. The most recent severe flooding occurred in 2007 and 2008 , with the northern region bearing the brunt of the damages. In 2007, over 127,880 people were affected, 13,764 people displaced, and dozens killed. In 2008, heavy rains unleashed severe floods in the northern Savannah, southern Maritime, and Central regions, displacing over 4,000 people. During both flood events, food security plummeted as prices skyrocketed, and inflation rates rose from $1 \%$ in 2007 to $9.1 \%$ in (ADB, 2008).

Drought - Drought events occur most frequently in the Kara and Savannah regions, where each year temperatures reach above $40^{\circ} \mathrm{C}$. Over the past 60 years, Togo has experienced three major droughts (between 1942-1943, 19761977, and 1982-1983) leading to severe famines. Droughts are characterized by a progressive increase in temperature, a decline in rainfall events, a reduction in the number of rainy days, and a shift in the ratio of rainfall to potential evapotranspiration. In addition to direct environmental impacts, such as soil degradation and loss of biodiversity, the socio-economic consequences of these events include a reduction in agricultural yields, death of livestock, reduction in agricultural revenue, an increase in rural to urban migration, exacerbation of famine, and an upsurge in water- and vector-borne diseases.

\section{Climatic Change and Agricultural Production in Togo}

Togo is one of the least developed countries in the world with a gross national income (GNI) of US $\$ 22.7$ billion and a population of more than 6 million (World Bank 2009). Agriculture is the source of livelihood to an overwhelming majority of the Togolese population and is the basis of the national economy, where small-scale subsistence farming is predominant. This sector employs more than $80 \%$ of the labour force and accounts for $40 \%$ of the GDP and $20 \%$ of the export revenue (Ministry of Finance and Economic Development 2006). Togo agriculture is heavily dependent on natural rainfall, with 
irrigation agriculture accounting for less than $2 \%$ of the country's total cultivated land. Thus, the amount and temporal distribution of rainfall and other climatic factors during the growing season are critical to crop yields and can induce food shortages and famine. A recent mapping of vulnerability and poverty in Africa (Orindi et al., 2006; Stige et al., 2006) put Togo as one of the countries most vulnerable to climate change with the least capacity to respond. Togo has suffered from periodical extreme climate events, manifested in the form of frequent drought (1942 $-1943 ; \quad 1976-1977$; and 1982-1983) and occasional flooding (1992 and 2007). Rainfall variability and associated droughts have been major causes of food shortage and famine in Togo. At the national scale, the link between drought and crop production is widely known. However, little evidence is available on how climate change affects farmers' adaptation strategies at the household level and the subsequent crop yield and revenues (notable exceptions are Seo and Mendelsohn 2008a,b and Di Falco et al., 2011). This is particularly important for designing effective adaptation strategies to cope with the potential impacts of climate change.

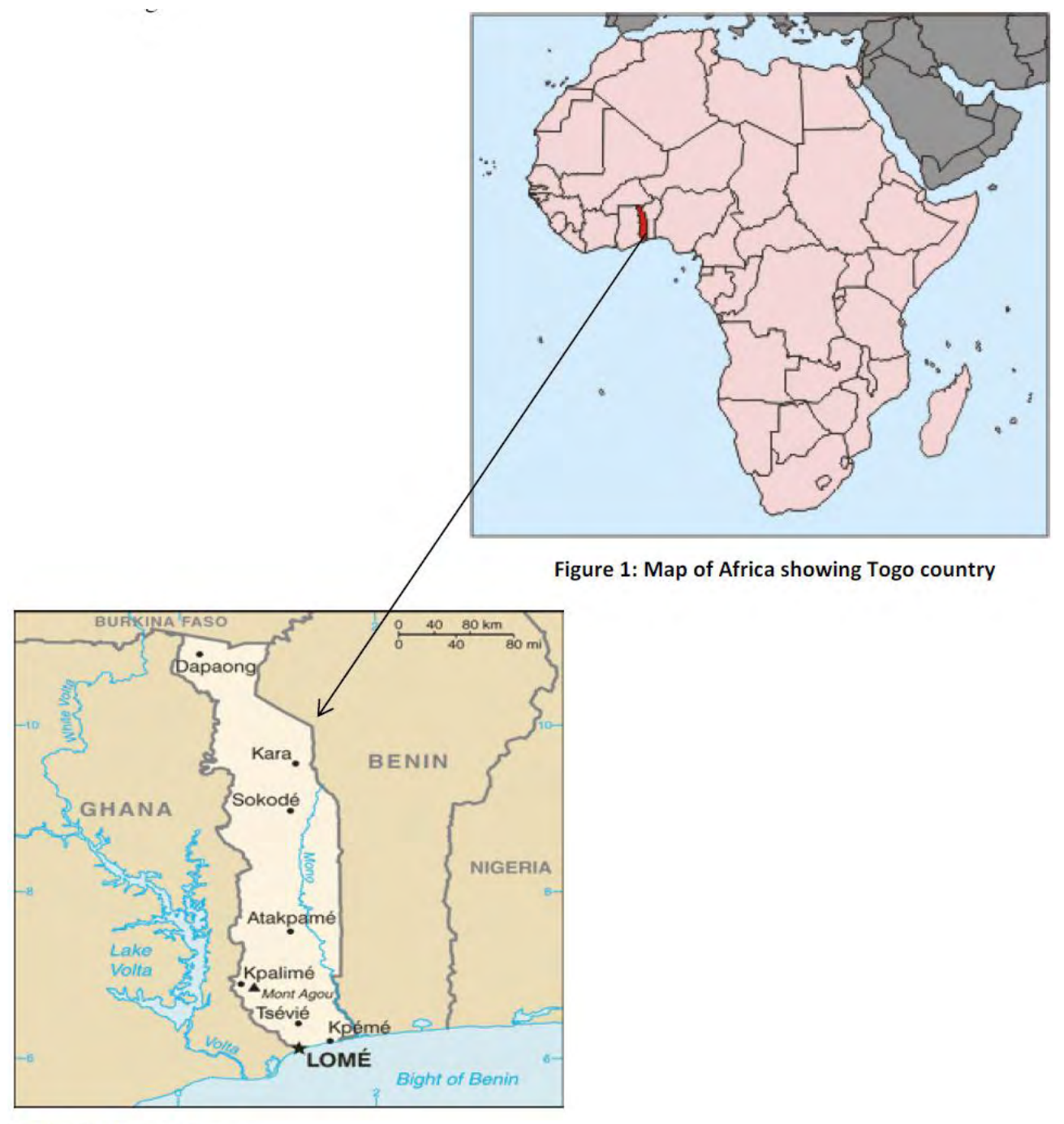

Figure 2: Map of Togo

\section{Measuring the Impact of Climate Change on Agriculture}

This study applies the Ricardian method developed by Mendelsohn et al. (1994) to measure the value of climate in US agriculture. This analysis is based on the assumption of a direct cause and effect relationship between climate events and farm value. The Ricardian method has been applied to assess the contribution of environmental conditions to farm income. Ricardian approach is preferred to the traditional estimation methods, given that instead 
of ad hoc adjustments of parameters which are characteristic of traditional approach; this technique automatically incorporates efficient adaptations by farmers to climate change (World Bank, 2003). Because it uses net revenues, the Ricardian approach reflects the benefits and costs of implicit adaptation strategies. More specifically, Ricardian analysis incorporates the substitution of different inputs and the introduction of alternative activities that each farmer has adopted in light of the existing climate (Kurkurlasuriya et al., 2006). The advantage to apply this model is that it is cost effective, since secondary data on cross-sectional sites can be relatively easy to collect on climate.

Despite some strengths, the Ricardian method as a cross-section analysis does not account for dynamic transition costs which can occur as farms move between two states. Likewise, Ricardian approach fails to fully control the impact of important variables that could also explain the variation in farm incomes. Another criticism of this method is that the assumption of constant prices is wrong (Cline,

$$
A A V=\alpha_{0}+\sum_{j=1}^{m}\left[\alpha_{j} T_{j}+\beta_{j} T_{j}^{2}+\delta_{j} P_{j}+\gamma_{j} P_{j}^{2}\right]+\sum \varphi_{i} E_{i}+\mu
$$

In this equation, the linear formulation of the model indicates the uni-directional impact of the independent variables on the dependent variable, while nonlinear term shows the non-linear shape of the net revenue of the climate response function. It is noteworthy to say that the net revenue function is U-shaped in case of quadratic term being positive and hill-shaped in case quadratic term being negative. Because land net value does not exist in the context of Togo we took agriculture added value as its proxy. Annual temperature and rainfall do not fully capture climate effect on agriculture. Drought spells during cropping season do not have the same impact as drought in non cropping season. For this reason we split annual year into cropping season and non cropping season. Thus $\mathrm{j}$ $=\{p, s\}$ where $p=$ cropping season and $s=$ non cropping season". The data used in this paper

$$
E\left[\partial A A V / \partial C_{i}\right]=\alpha_{1, i}+2 * \alpha_{2, i} * E\left[C_{i}\right]
$$

include therefore: $\mathrm{T}_{\mathrm{s}}$ (mean temperature of non cropping seasons), $T_{p}$ (mean temperature of cropping season), AAV (agricultural added value), $E_{1}$ fertilizer, $E_{2}$ agricultural machinery, $E_{3}$ agricultural population in percentage of total population, $E_{4}$ agricultural land, $E_{5}$ irrigated land in percentage of agricultural land. The data we used in this paper come from two main sources namely World Development indicators databank and Togo national meteorological service for climate variables.

Marginal values are often calculated to measure the marginal impacts of a change in climate variables and these values depend on the regression equation which is being used and the climate which is being evaluated. The expected marginal impact of a single climate variable, $C_{i}$ on net farm income evaluated at the mean is:

Where climate variable $C_{i}$ in this study stand for temperature and precipitation $\left(T_{j}, P_{j}\right)$.

\section{Econometric Method}

The application of Augmented Dickey-Fuller Test (ADF Test) revealed that all series are stationary in first difference. Therefore the first intuition is to make an estimate of an Error
Correction Model (ECM). To be certain of the reliability of the estimates, we tested the hypothesis of cointegration series through Johansen cointegration test which confirms series cointegration. The model must be estimated by the technique of error correction 
models. In our work we followed Engel and Granger two steps error correction model. The long term equation is therefore

$$
\begin{aligned}
& A A V=\alpha_{0}+\varphi_{1} E_{1}+\varphi_{2} E_{2}+\varphi_{3} E_{3}+\varphi_{4} E_{4}+\varphi_{5} E_{5}+\alpha_{1} P_{p}+\alpha_{2} P_{S}+\gamma_{1} T_{P}+\gamma_{2} T_{S}+\beta_{1} P_{P}^{2}+ \\
& \beta_{2} P_{S}^{2}+\gamma_{3} T_{P}^{2}+\gamma_{4} T_{S}^{2}+e_{t}
\end{aligned}
$$

While the short term relation is given by

$$
\begin{gathered}
D(A A V)=\varphi_{0}+\varphi_{6} D\left(E_{1}\right)+\varphi_{7} D\left(E_{2}\right)+\varphi_{8} D\left(E_{3}\right)+\varphi_{9} D\left(E_{4}\right)+\varphi_{10} D\left(E_{5}\right)+\alpha_{3} D\left(P_{p}\right)+ \\
\alpha_{4} D\left(P_{S}\right)+\gamma_{3} D\left(T_{p}\right)+\gamma_{4} D\left(T_{S}\right)+\beta_{3} D\left(P_{p}^{2}\right)+\beta_{4} D\left(P_{S}^{2}\right)+\gamma_{5} D\left(T_{p}^{2}\right)+\gamma_{6} D\left(T_{S}^{2}\right)+\emptyset e_{t-1}+\varepsilon_{t} \\
\text { Where } D \text { is the first difference operator: } D\left(X_{t}\right)=X_{t}-X_{t-1}
\end{gathered}
$$

\section{Results and Discussion}

The coefficient associated with the error term delayed (-1.186354) is negative and significantly different from zero at statistical threshold of $5 \%$ (table 2). This indicates that there is a mechanism for error correction. In long-term imbalances between the agricultural values added per hectare, the number of tractors per hectare, the number of farmers per hectare, the amount of fertilizer per hectare, the mean precipitation of cropping season, mean precipitation of non cropping season, the mean temperature of cropping season, the share of irrigated land and the mean temperature of non cropping season have similar evolution. The coefficient -1.186354 reflects the speed at which the imbalance between the desired level and strength of the agricultural value added per hectare (farm income per hectare) is absorbed in the year following a shock. Thus, the impacts on farm income per hectare in Togo are corrected by the feedback effect. In other words, a shock in a given year on agricultural income is fully absorbed after 0.84 years $(1 / 1.186354)$ is about 10 months.

The sign of precipitation does not form a surprise. It reflects the positive effect of increased precipitation on agricultural income in both the short and long term. Indeed, $1 \mathrm{~mm}$ more water, in the short term, during the cropping season on average increases farm income per hectare by 84 cent while it increases by 8 dollars 84 cents in the long term. The coefficient of the square rainfall is significantly negative in the short term (table 2). This indicates that farm

Table 3 Agricultural value added per hectare in Togo as projections to 2100 at constant prices (2000 U.S. dollars)

\begin{tabular}{lll}
\hline Precipitation variation & $\begin{array}{l}\text { Per hectare agricultural value added } \\
\text { variation in level }\end{array}$ & $\begin{array}{l}\text { Per hectare agricultural value added } \\
\text { variation in percentage }\end{array}$ \\
\hline Decrease of 1.4\% (2025) & -41.35 & $-7.11 \%$ \\
Decrease of 3\% (2050) & -88.58 & $-15.24 \%$
\end{tabular}

income is a concave function of rainfall. There is therefore non linear relationship between agricultural added value and precipitation during the cropping season. This is consistent with intuition. Indeed, it is reasonable to think that at a certain level, increase rainfall has a negative effect on farm income due to flooding.

The use of irrigation techniques is favourable to agricultural added value in the short (a significantly positive coefficient of 4.18) as well as in the long term (a significantly positive coefficient of 11.23).

\section{Climate change impacts on agricultural performances}

From the parameters estimated above (tables 1 and 2) it can be highlight the impact of climate change on the performance of agriculture from climate scenarios for Togo. Climate scenarios for Togo are those constructed from MAGICC / SCENGEN (Agbossou, 2009) horizons 2025 and 2050. Simulations made led to an overall increase in temperatures ranging from 1.5 to 5.3 ${ }^{\circ} \mathrm{C}$ between latitudes of Togo. Precipitations in turn, would present trend depending on latitude. Between $6^{\circ}$ (Lomé) and $10^{\circ}$ (Kante) north latitude, rainfall suffers a decrease of up to $1.4 \%$ in 2025 and $3 \%$ in $2050.10^{\circ}$ to $11^{\circ}$ north latitude (Region des savanes), they undergo an increase up to $0.8 \%$ in 2025 and $2 \%$ in 2050. Considering plausible scenarios of increased temperatures of $1.5^{\circ} \mathrm{C}$ in 2025 and $5.3^{\circ} \mathrm{C}$ by 2050 and a decrease in precipitation of $0.14 \%$ in 2025 and 3\% in 2050, the simulated impacts are summarized in the table below: 
Table 3 shows that farm income per hectare will be negatively affected by climate change. Indeed, farm income per hectare suffer a decline of between 14 and 88 U.S. dollars (constant 2000 \$) relative to that of 2004 ; decline caused by projected reduced rainfall. This decrease corresponds to a percentage between 7.11 and 15.2 percent of farm income per hectare. In terms of GDP, climate change will cost Togo a proportion between 2.84 and 6 percent. These analyzes are consistent with what one might think because of the low average precipitation during the rainy season $(550 \mathrm{~mm}$ average water against a threshold $924 \mathrm{~mm}$ of rainfall). However, it is clear that agriculture does not necessarily win in a rush though abundantly increased precipitation. As an indication, from an average rainfall of the rainy season close to $924 \mathrm{~mm}$ of water, increasing the average level of precipitation negatively impact the agricultural added value. The importance of this study derives its source from the establishment of the relationship between climatic variables and farm income. Indeed, the impact of rainfall on agricultural income is positive, and all climate projections indicating in general a decrease of rainfall for West Africa, this is a confirmation that future climate change will have a negative impact on farm income per hectare in Togo. It is therefore crucial for the authorities in charge of the agricultural sector in Togo to act now.

\section{Conclusion}

Climate change is widely acknowledged as the global concerned due to its large effects on human life. Climate change can have multiple impacts on livelihoods of people. For instance, impacts of climate variability and change on agricultural sector are projected through changes in land and water regimes, the likely primary conduits of change. Therefore, it is obviously a matter of concerned for policymakers and economists regarding its impact on the livelihoods. This paper thus aims to shed light on the impact of climate change on Togolese agriculture using time series data of the period 1971-2004. The study applies Ricardian approach to measure the impact of climate change on agriculture in which net crop output is regressed with both climate and other variables. The explanatory variables include the linear and quadratic terms of precipitation and temperature for the two seasons (cropping and non cropping seasons), ratio of irrigated land, fertilizer, agricultural labour and agricultural machinery.
We are careful to handle some of the estimation problems such as multicolinearity and autocorrelation, often arisen on time series data in the application of nonlinear models. The findings show a significant impact of climate variables on net farm income per hectare in Togo during the growing season, indicating both positive and non significant impact of precipitation and temperature respectively during the growing season. Net farm income is likely to increase with high precipitation during the rainy periods which are the major growing seasons of Togo. Farmers are therefore likely to increase their revenue with relatively enough precipitation during rainy period. Other explanatory variables have also impact on agricultural added value. For instance, net farm income is likely to be increased by irrigated farm land. The quadratic terms of precipitations of rainy season have negative impact on agricultural added value per hectare. Cropping period's precipitation is likely to increase crop output in hills. Finally, the study focuses on the impact of climate change on agriculture using Ricardian approach; we found some interesting results to understand the impact of climate change on Togolese agriculture. As there is a variation in the impact of the climate change (i.e. change in precipitation and temperature) on agriculture in different seasons, the policy needs to address these variations while formulating the adaptation and mitigation strategies of the negative impact of climate change in the country. Climate change impacts are driven by decreases in precipitations implies that adaptation efforts should target more droughtresistant crop varieties and technologies. Since, this study applies only a Ricardian approach to measure the impact of climate change on agriculture, further research and study using more advanced models, such as agro-economic, CGE and bio-economic models to measure the impact of climate change on agriculture is needed.

\section{References}

Cline,W. R.1996. "The impact of global warming on agriculture: Comment." The American Economic Review 86(5): 1309-1301. Kurukulasuriya, P. and Mendelsohn, R. (2008), "A ricardian analysis of the impact of climate change on Africa croplanold, The wold bank, Washington, DC.d; policy research working paper 4305. 
Langlois, F., (2006), Influence de la variabilité de la pluie sur la production agricole dans le bassin de la Volta : exemple du maïs. Volta Basin Focal Project Report. No1 ;IRD,Montpellier, France, and CPWF, Colombo, Sri Lanka, 51 p.

Mendelsohn, R. and Nordhaus, W. (1999). The impact of global warming on agricuture : A ricardian analysis. The economics review. Vol $89 \mathrm{~N}^{\circ} 4$.

Mendelsohn, R., Dinar, A. and A. Sanghi (2001). The effect of development on the climate sensitivity of agriculture. Environment and Development Economics, 6, pp 85-101.

Mendelsohn R., Dinar A. and A. Dalfelt (2000)," Climate change impact on african agriculture" Yale University press.
Mendelsohn, R., W. Nordhaus, and D. Shaw. 1994. "The Impact of Global Warming on Agriculture: A Ricardian Analysis" American Economic Review.

Olivier Deschênes and Michael Greenstone. The economic impacts of climate change: Evi-dence from agricultural products and randomfluctuations in the weather. American Economic review.

William R. Cline Global warming on agriculture: A Ricardian analysis. American Economic Review, 84(4):753.771,1994.

Wold bank (2007). Wold development indicators. Online edition. Washington, D.C: The Wold bank.

Table 1 Long term equation estimation result

\begin{tabular}{|c|c|c|c|c|}
\hline Variables & Coefficients & Std. Error & t-Statistic & Prob \\
\hline Constant & -9647.697 & 13929.43 & -0.692612 & 0.4958 \\
\hline Fertilizer & 4509.396* & 784.1732 & 5.750511 & 0.0000 \\
\hline agricultural machinery, & $-1984132 *$ & 254970.5 & -7.781808 & 0.0000 \\
\hline agricultural population & $155.7769 *$ & 13.11871 & 11.87441 & 0.0000 \\
\hline agricultural land & $2.6501^{*}$ & 1.09130 & 2.429255 & $\mathbf{0 . 0 2 3 7}$ \\
\hline irrigated land & $11.2390^{*}$ & 1.56335 & 7.18902 & 0.0000 \\
\hline Non cropping season mean precipatation & 1.231530 & 1.069822 & 1.151153 & 0.2620 \\
\hline cropping season mean precipitation & $2.651055^{*}$ & 1.091304 & 2.429255 & 0.0238 \\
\hline cropping season mean temperature & 1066.778 & 1071.495 & 0.995598 & 0.3303 \\
\hline Non cropping season mean temperature & -309.1434 & 1213.861 & -0.254678 & 0.8013 \\
\hline Cropping season mean precipitation square & -0.001301 & 0.001206 & -1.078587 & 0.2925 \\
\hline Non cropping season mean precipatation square & $-0.010459 *$ & 0.005018 & -2.084354 & 0.0489 \\
\hline Non cropping season mean temperature square & 5.873128 & 21.19292 & 0.277127 & 0.7843 \\
\hline Cropping season mean temperature & -21.33875 & 20.74779 & -1.028483 & 0.3149 \\
\hline$R^{2}$ & \multicolumn{2}{|c|}{0.897227} & & \\
\hline F-statistic & \multicolumn{2}{|c|}{27.19051} & & \\
\hline $\operatorname{Prob}(F$-statistic $)$ & \multicolumn{2}{|c|}{0,00000} & & \\
\hline
\end{tabular}


Table 2 Short term equation estimation results

\begin{tabular}{|c|c|c|c|c|}
\hline Variables & coefficients & Sdt.Error & t-Statistic & Prob \\
\hline Constant & -2624.171 & 17807.17 & -0.147366 & 0.8843 \\
\hline D(Fertilizer) & 292.8649 & 1354.799 & 0.216169 & 0.8310 \\
\hline D(Agricultural machinery) & $-4659307 . *$ & 1974096. & -2.360223 & 0.0285 \\
\hline D(Agricultural population) & 238.9926* & 69.26202 & 3.450558 & 0.0025 \\
\hline D(Agricultural land) & 20.3567 & 27.95459 & 0.728209 & 0.4749 \\
\hline $\mathrm{D}$ (Irrigated land) & $4.1895^{*}$ & 1.4445 & 2.900249 & 0.0088 \\
\hline $\mathrm{D}$ (Cropping season mean precipitation) & $4.254592 *$ & 1.466975 & 2.900249 & 0.0088 \\
\hline $\mathrm{D}$ (Non cropping season mean precipatation) & 2.245005 & 1.253257 & 1.791336 & 0.0884 \\
\hline $\mathrm{D}$ (cropping season mean temperature) & 1431.552 & 1448.691 & 0.988169 & 0.3349 \\
\hline $\mathrm{D}$ (Non cropping season mean temperature) & -1158.632 & 1600.343 & -0.723990 & 0.4775 \\
\hline $\mathrm{D}$ (Cropping season mean precipitation square) & $-0.004620 *$ & 0.001648 & -2.803007 & 0.0110 \\
\hline $\mathrm{D}$ (Non cropping season mean precipatation square) & -0.009152 & 0.005599 & -1.634681 & 0.1178 \\
\hline $\mathrm{D}$ (Cropping season mean temperature square) & 20.35679 & 27.95459 & 0.728209 & 0.4749 \\
\hline (Non cropping season mean temperature square) & -28.41556 & 28.00859 & -1.014530 & 0.3224 \\
\hline$e_{t-1}$ & $-1.186354 *$ & 0.343207 & -3.456673 & 0.0025 \\
\hline $\boldsymbol{R}^{2}$ & 0.774043 & & & \\
\hline F-statistic & 10.13500 & & & \\
\hline $\operatorname{Prob}(F$-statistic $)$ & 0.000005 & & & \\
\hline
\end{tabular}

